\title{
Status, distribution and ecology of the White-breasted Parakeet Pyrrhura albipectus in Podocarpus National Park, southern Ecuador
}

\author{
E. P. TOYNE, M. T. JEFFCOTE and J. N. FLANAGAN
}

\begin{abstract}
Summary
The White-breasted Parakeet Pyrrhura albipectus, a threatened parrot known from three general areas of south-east Ecuador, was investigated in the only one of these areas to receive any protection, Podocarpus National Park, in 1990 and 1992. Its habitat there is upper tropical and subtropical forest, with some evidence that it can tolerate disturbed areas; six food-plants were added to the one (liana) already known, two euphorbs, another liana, a Miconia, a Ficus and Mollia gracilis (on which feeding was regular in August and September). Food-passing to one possible and another evident juvenile at this time suggested local breeding. Three adult and one juvenile call were distinguished. The species was found at nine sites in or immediately adjacent to the park, but mining concessions, currently suspended, may soon be granted and the park thereby seriously affected.
\end{abstract}

Pyrrhura albipectus es un psitácido amenazado conocido exclusivamente en tres zonas del sudeste de Ecuador; en 1990 y 1992 se estudió en el Parque Nacional Podocarpus (única zona donde recibe algun tipo de protección). El hábitat en el área está constituido por bosque tropical y subtropical de las cotas más elevadas, con cierta evidencia de que la especie puede tolerar hábitats alterados; seis tipos de plantas se añaden a la dieta hasta ahora conocida para la especie (una liana), éstas incluyen: dos euforbias, otra liana, una Miconia, un Ficus y Mollia gracilis (de la que se alimentaba de forma regular en agosto y septiembre). Se detectó transferencia de alimentos de un adulto a un juvenil y a un segundo posible juvenil, lo que sugiere reproducción local. Se identificó el reclamo de tres adultos y un juvenil. La especie fue localizada en nueve zonas del parque o en su inmediata proximidad, pero concesiones mineras, detenidas en la actualidad, pueden ser subvencionadas con el consiguiente impacto a la integridad del parque.

\section{Introduction}

The White-breasted Parakeet Pyrrhura albipectus is a threatened species endemic to south-east Ecuador, all recorded sightings (reviewed by Collar et al. 1992) being from three general areas: the Cordillera de Cutucú, Zamora-Chinchipe province (Robbins et al. 1987), two sites on the west slope of the Cordillera del Condor, in Morona-Santiago province (J. M. Carrión verbally 1991, Krabbe in prep.), and the Zamora area of Zamora-Chinchipe province, which includes the Loja-Zamora road (Chapman 1914, 1926, Ridgely 1981, Platt 1989, Bloch et al. 1991, Toyne and Jeffcote 1992). The last location includes sightings at the Rio Bombuscara and Romerillos entrances to the Podocarpus National Park (Platt 1989, Bloch et al. 1991, Toyne and Jeffcote 1992, C. Rahbek et al. verbally 1992). 
All sightings were within the 1,000-2,000 $\mathrm{m}$ elevational range. Several searches for the parakeet in the Zamora area and the Cutucú mountains have proved unsuccessful (Ridgely 1981, Robbins et al. 1987), leading to the speculation that its occurrence there might be seasonal (Ridgely 1981).

The White-breasted Parakeet was recently judged to fall into the IUCN status category "Insufficiently Known", and listed with other birds "for which further protection is desirable" (Collar et al. 1992). Current possible threats to its status in the Podocarpus National Park include habitat degradation resulting from illegal colonization, hunting and small-scale trapping, with captive parakeets found in surrounding areas and in Quito (P. Greenfield in litt. 1991, Toyne and Jeffcote 1992). Information on population size is difficult to assess, but current estimates suggest that the species may number no more than a few thousand individuals (Collar et al. 1992).

There is some speculation concerning the taxonomic status of the Whitebreasted Parakeet. Robbins et al. (1987) observed it in mixed flocks with the Maroon-tailed Parakeet Pyrrhura melanura at an altitude of 1,000-1,200 $\mathrm{m}$ in the Cordillera de Cutucú. Individual White-breasted Parakeets in these mixed flocks showed morphological differences from individual White-breasted Parakeets seen at an altitude of $1,200-1,700 \mathrm{~m}$. It is unclear whether the differences were age-related or due to albipectus $\times$ melanura hybridization. It may simply be that the White-breasted Parakeet and Maroon-tailed Parakeet remain separated during the breeding season, each utilizing a different altitudinal range, and outside the breeding season they group to form such mixed flocks (Robbins et al. 1987).

The known ecology of $P$. albipectus suggests that it is similar to that of other parakeets, travelling noisily in small flocks of 4-20 individuals and foraging in the fruiting trees and flowering lianas (e.g. Piptocarpha cf. poeppigiana) of primary forests or partially cleared areas (Ridgely 1981, Forshaw 1989, Bloch et al. 1991, Krabbe in prep.). In this paper we present further data on its food habits and new information on vocalizations and the juvenile plumage. We also document its status and distribution in the Podocarpus National Park, the only protected area where it is known to occur.

\section{Study area and methods}

Podocarpus National Park straddles the Andes of southern Ecuador, covering an area of approximately 146,000 ha in the provinces of Loja and ZamoraChinchipe. It was established in December 1982 and is named after the podocarpus Podocarpus tree, Ecuador's only native conifer genus. Although goldmining concessions are currently (1992) suspended, in 1991 they covered over $99 \%$ of the park's area, and may again be granted in 1993; moreover, there is illegal colonization in several areas (Calderón undated).

During the periods August-September 1990 and March-June 1992 we surveyed various localities within the park (Figure 1 ). This work concentrated on the upper tropical and subtropical areas of the park on the east side of the Andes within the altitudinal range $P$. albipectus inhabits.

Vocalizations were recorded using a Sony stereo cassette-corder $\mathrm{TCD}_{3}$, an Audio-technics AT 9300 microphone and a parabolic reflector. Recordings were 
deposited with the British Library of Wildlife Sounds (BLOWS) at the National Sound Archive in London. Sonagrams were produced on a voice-identifying KT 1000 digital spectrograph using a wide bandwidth $(300 \mathrm{~Hz})$. Standardized techniques were employed for cataloguing food-plants (Lawrence 1951, Mori and Prance 1987). Botanical specimens were deposited at the National Herbarium of the Museo Ecuatoriano de Ciencias Naturales, Quito, and at the Royal Botanic Gardens, Kew.

\section{Results}

\section{Status and distribution}

The White-breasted Parakeet was located in the general areas of Zamora, Romerillos and Quebrada Honda at nine sites: Río Bombuscara, El Limón, Serranía, Curintza, Romerillos, Quebrada Danta, Quebrada Avionetta, between Dos Camas and San Luis, and Quebrada Honda (Figure 1).

Rio Bombuscara c. $4^{\circ} 08^{\prime} S 78^{\circ} 58^{\prime} \mathrm{W}(900-1,400 \mathrm{~m})$ At the Río Bombuscara entrance to the park, a $4 \mathrm{~km}$ pre-cut trail on the west bank of the river was surveyed from 19 August to 5 September 1990 and in 1992 on the following days: 31 March-1 April, 28-29 April and 1 May. This trail follows the river and leads to settlements inside the park where colonists farm crops and ranch cattle. The surrounding habitat was mostly undisturbed upper tropical forest with an open canopy. Species of the families Bromeliaceae, Meliaceae, Lauraceae, Rubiaceae and Tilliaceae predominated, along with ferns Pteridophytas. During our first visit $P$. albipectus was regularly seen (15 out of 17 days). On our return in 1992, birds were observed twice in April, once as a flock of nineteen individuals.

The Río Bombuscara is not named on the map of the Zamora area (IGM 1981b) but is on the adjoining Río Sabanilla map (IGM 1981a). The area is also known as Bombuscaro (Platt 1989) and the field centre is called Bombuscaro by the Ministerio de Agricultura.

El Limón c. $4^{\circ} 03^{\prime} S 78^{\circ} 57^{\prime} \mathrm{W}(1,100-1,700 \mathrm{~m})$ The subtropical forests south of the village of El Limón on the edge of the park were surveyed from a pre-cut trail on 17-20 August 1990 and 29 March 1992. Habitat was as at Bombuscara but with more extensive clearances for agriculture at the lower elevations. Whitebreasted Parakeets were not located in 1990, but were seen in 1992: two flocks of three and two individuals were encountered at $1,700 \mathrm{~m}$, the latter being observed foraging.

Serrania c. $4^{\circ} 02^{\prime} S 79^{\circ} 00^{\prime} W(1,150-1,600 \mathrm{~m})$ This location is between El Limón and Sabanilla (IGM 1981a) and was investigated on 2 May 1992. The forest starts at the edge of the Loja-Zamora road and extends south uphill to the Podocarpus National Park. The area surveyed was outside the park and heavily colonized by farmers. A pre-cut trail was used for access into the remaining forest, which also led through large agricultural clearances. A flock of six $P$. albipectus was observed at $1,400 \mathrm{~m}$ in forest that bordered land cleared for farming. 


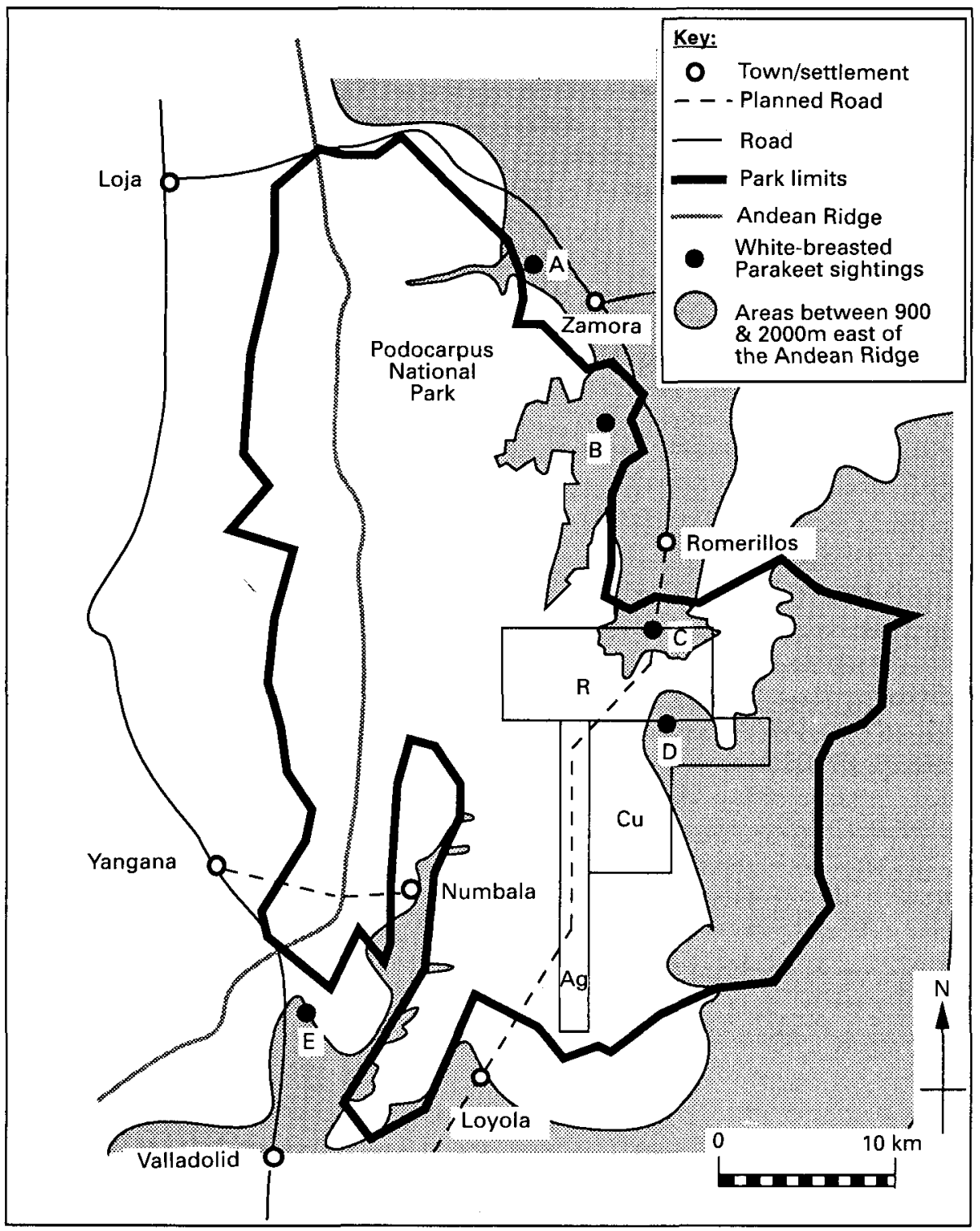

Figure 1. Location of White-breasted Parakeet sightings in and around Podocarpus National Park in relation to their potential distribution as defined by areas between 900 and 2,000 $\mathrm{m}$. Approximate locations of sightings are indicating by A, Serranía, El Limón and Loja-Zamora road; B, Río Bombuscara and Curintza; C, Quebradas Avionetta and Danta; D, Dos Camas; E, Quebrada Honda. The approximate location of gold-mining concessions within the park is indicated by the rectangular areas marked $\mathrm{R}$, Romerillos; $\mathrm{Au}$, Augusta; and $\mathrm{Cu}$, Cumbinama (source: Mineral permits and contracts map: Cumbinamasa and RTZ joint venture and Augusta concession map, 27/10/88, Cumbinamasa, S.A.). 
Curintza c. $4^{\circ} 08^{\prime} S 78^{\circ} 58^{\prime} W(1,100-1,600 \mathrm{~m})$ The forest on the edge of the park, approximately $4 \mathrm{~km}$ west of the village of La Pituca, was investigated over 1-3 May 1992. Habitat was similar to Bombuscara with areas of colonization occurring within the park. Access to the forest was via a pre-cut trail which serves the colonists in this area. From the trail White-breasted Parakeets were observed in flocks of two, seven, eight and 10 individuals on four occasions.

Romerillos (also Quebradas Danta and Avionetta, Dos Camas) c. $4^{\circ} 13^{\prime} \mathrm{S} 78^{\circ} 54^{\prime} \mathrm{W}$ $(1,400-2,500 \mathrm{~m})$ This area was investigated during two visits. First, the forest $1 \mathrm{~km}$ south of the village of Romerillos was surveyed on 29 April 1992. Here six albipectus were seen flying along the Río Jambue $(c .1,500 \mathrm{~m})$. On the second trip (19-23 May 1992) we followed the "Romerillos loop" (Rachowiecki and Wagenhauser 1992). A log path constructed by mining companies was walked. This followed the course of the Quebrada Danta, and for two hours it led us through heavily degraded habitat alongside the quebrada where White-breasted Parakeets were encountered in flocks of two and seven individuals at $1,600 \mathrm{~m}$. From the park boundary to Dos Camas (c. $\left.4^{\circ} 20^{\prime} \mathrm{S} 78^{\circ} 54^{\prime} \mathrm{W}\right)$ some forest had been cleared by colonists and mining companies. $P$. albipectus was also encountered on 20 May just before Dos Camas, on the border of Romerillos and Cumbinama gold-mining concessions (Figure 1 ). Here they were seen in flocks of two and eight individuals alongside the same quebrada (c. 1,400-1,600 $\mathrm{m}$ ). They were also heard at Dos Camas $(c .1,600 \mathrm{~m})$ on the same day. The trail continued through pristine, humid montane forest until the ridge was reached near $\mathrm{La}$ Cumbre mining settlement $(2,465 \mathrm{~m})$. Between Dos Camas and La Cumbre at c. $1,800 \mathrm{~m}$ a flock of five albipectus was observed. The trail returns to Romerillos in a loop, following the Quebrada Avionetta, where at lower altitudes and in partially degraded habitat we saw groups of five, seven and eight albipectus on 23 May at $1,500-1,800 \mathrm{~m}$.

Quebrada Honda c. $4^{\circ} 30^{\prime} \mathrm{S} 79^{\circ} \mathrm{O} 4^{\prime} \mathrm{W}(1,500-1,800 \mathrm{~m})$ This area was accessed along a pre-cut trail used by colonists and is just south of the park (Figure 1). It was first visited during 27-31 August 1990 and again 29 March-2 April 1992. The habitat of the quebrada is disturbed subtropical forest with high concentrations of podocarpus trees. No albipectus was found in 1990, but nine were seen perched and then flying across a cleared hillside at 1,600 m on 29 March 1992.

\section{Flock-size and flight description}

Flock-size was variable. At the main study site, Río Bombuscara, the commonest flock-size was 5-8 individuals, but the number varied from three to 19 parakeets as flocks were regularly seen joining and separating. Data collected in 1992 from nine locations gave a mean flock-size of approximately seven $(n=17)$.

The parakeets flew fast and just above the tree canopy. This was also the case when they used rivers as flyways. Only once were they seen flying high in the sky. 


\section{Food sources}

During the study White-breasted Parakeets were recorded feeding on six species of plant as itemized below, all observations except the last being in the Río Bombuscara area.

1. Mollia gracilis Spruce ex Benth. (Tilliaceae)

This tree produced pods containing seeds which were eaten in August and September. It is distributed over Amazonian Ecuador, Peru, Colombia, Venezuela and western Amazonian Brazil (T. Pennington verbally 1991). Local foresters called it "copal silvestre".

\section{Ficus sp. aff. mutisii Dugand (Moraceae)}

This tree was known locally as "higuerón" and produced fleshy fruits eaten by the parakeets in August and September. It is of uncertain identification and distribution. It is either mutisii or a close relative, mutisii being sparsely recorded in central Colombia and northern Ecuador (M. Thomas verbally 1992).

3. Miconia cf. punctata (Desr.) Don. ex DC. (Melastomataceae)

Members of this family are common food sources for parrots (Forshaw 1989) and the parakeets fed on the fleshy fruits of this tree in August and September. The species is distributed from southern Mexico and the Greater Antilles to the Amazon drainage in Brazil, Peru, Bolivia and Ecuador (Wurdack 1980).

4. Mikania leiostachya Benth. (Asteraceae)

This liana bore small flowers in August and September which the parakeets ate. The species is restricted to Colombia and Ecuador within the elevational range $0-1,000 \mathrm{~m}$ (T. Pennington verbally 1991), although this specimen was found slightly higher, at $1,100 \mathrm{~m}$.

5. Alchornea glandulosa Poepp. (Euphorbiaceae)

A mature tree bore small green fruits in March which the parakeets ate. The species is distributed from Costa Rica through Panama to Colombia, Venezuela, Ecuador, Peru and Bolivia (A. Radcliffe-Smith verbally 1992).

6. Tetrorchidium macrophyllum Muell. Arg. (Euphorbiaceae)

The parakeets were observed in March, at El Limón, eating the tree's small red berries. This species is confined to Ecuador and Peru (A. Radcliffe-Smith verbally 1992).

\section{Feeding behaviour}

At Río Bombuscara, a total of 1,956 minutes were spent making observations on 18 different occasions when White-breasted Parakeets fed. This period included times when the birds were resting. On 14 of the 15 days that the species was observed, it was regularly seen near the Bombuscara field centre visiting Mollia gracilis. Observational data were collected whilst the parakeets fed on Mollia gracilis for 1,104 minutes. The parakeets usually visited this tree in the mornings before flying upstream and would normally return in the afternoon.

Visiting periods varied from four to 452 minutes, with the birds leaving quickly on two occasions owing to human disturbance and the presence of a raptor. The average duration of a visit, including the above two occasions, was 132 minutes. 
The seeds of Mollia gracilis are located within spherical pods $1 \mathrm{~cm}$ in diameter which are attached to the leaf branches by stalks $2 \mathrm{~cm}$ long. Whilst searching for seed-pods the parakeets would move upwards along branches, periodically descending to repeat the search. A preference was shown for green seed-pods as opposed to yellow or brown pods, which were older and probably tougher to eat. The parakeets ate only the body of the seed, discarding the pod and seed wings. The discarded material was examined and several intact seeds were found within the pod. In March 1992 the parakeets were not observed feeding on Mollia gracilis and another examination of the pods revealed that they were newly formed and probably too young for parrot consumption.

Whilst attempting to procure Mollia gracilis seeds, two techniques were adopted by the parakeets: (1) the bill was used to remove the pod from the branch at the stem, the pod was then transferred to the claw and the seeds removed from the pod with the bill (the fruits of Ficus mutisii were observed eaten in the same manner); (2) when the pod was in an awkward location the parakeet would peck directly at it to remove the seed.

On three occasions parakeets were observed drinking water which had collected in epiphytic plants in their food trees. They were also found to drink from a waterfall that ran into the Río Bombuscara: this sometimes involved individuals submerging their whole heads into the waterfall, e.g. when drinking upside down whilst hanging onto nearby vegetation with their claws (C. Rahbek et al. verbally 1992).

\section{Description and behaviour of juvenile}

On 28 August 1990, a food pass, which involved an adult feeding another bird, was witnessed indicating a possible juvenile within the flock. The food pass was initiated by the recipient through loud chirping calls accompanied by fluttering of the wings. The only noticeable difference in appearance between the two birds was the paler orange auricular patch of the recipient. This bird flew competently and was seen to lead the flock at one stage.

On 4 September 1990, a juvenile was observed for a total of 452 minutes in a flock with four other birds that fed on Mollia gracilis. The juvenile differed from other members of the flock first in its inability to feed itself and second in appearance. It was observed several times attempting to feed, but it was unable to hold and open the pods. It was also observed trying to strip bark off the tree with its bill.

The appearance of this juvenile differed from the description of an adult $P$. albipectus given by Forshaw (1989) in the following ways: size approximately $20 \mathrm{~cm}$ (adults are $24 \mathrm{~cm}$ ), fawn (grey-blue) crown with no noticeable reddishbrown frontal band (adults have a greyish-brown crown with frontal band), light orange auricular patch (adults have orange-yellow ear-coverts and we have seen individuals with strong orange-red auricular patches), white chest with cream upper belly (adults have a white collar merging into the yellow of the breast), rest of belly and flanks lime green (adults have abdomen tinged with reddish-brown and have duller green flanks), white bill greying to base (adults' bills are greyish-brown). 


\section{Vocalizations}

Several vocalizations were recorded whilst the parakeets visited Mollia gracilis to feed. However, the tree was situated next to the Rio Bombuscara which caused a considerable amount of background noise and affected the quality of the recording. The different call types of $P$. albipectus are similar to those of other parakeets in being based on a different arrangement of the same syllable, with the variation of calls resulting from the timing of the repetitions (Forshaw 1989). This is illustrated in the similarity of the notes in each sonagram.

Foraging vocalizations The parakeets were recorded giving repetitive one-note calls, either "skee" or "week". These single chirps were repeated at approximately 0.6 second intervals and were assumed to be contact calls. The frequency range for these vocalizations was $1.1-6.6 \mathrm{kHz}$ (Figure 2a). A higher-pitched two-note "skee week" was given among contact calls. Figure $2 b$ shows the "skee week" call followed by two one-note calls.

Pre-flight call This call was recorded prior to a flock of parakeets leaving Mollia gracilis and was an erratic acceleration of the single note foraging contact call. One parakeet started calling and the other members of the flock joined in. The call is best described as a pre-flight clamour and occurred whenever the parakeets left any tree. The frequency of this call ranged from 1.0 to $7.2 \mathrm{kHz}$.

Flight call The flight call of albipectus was a constant series of rapid "squawks" at 0.18 second intervals (Figure $2 c$ ). The individual "squawk" was composed of a fundamental frequency followed by four harmonics, within the range 1.0-6.3 $\mathrm{kHz}$.

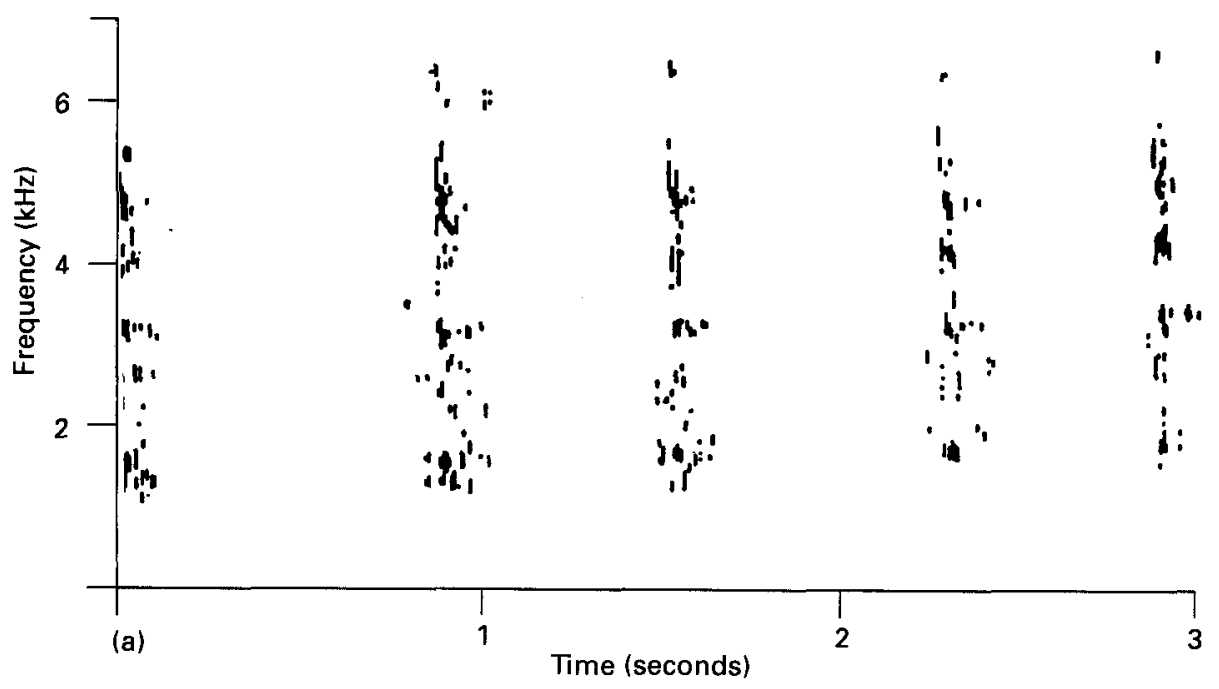

Figure 2. $2 a-c$. Sonagrams of the White-breasted Parakeet. a Foraging call, "skee" or "week". $b$ Foraging call, "skee-week". $c$ Flight call. 

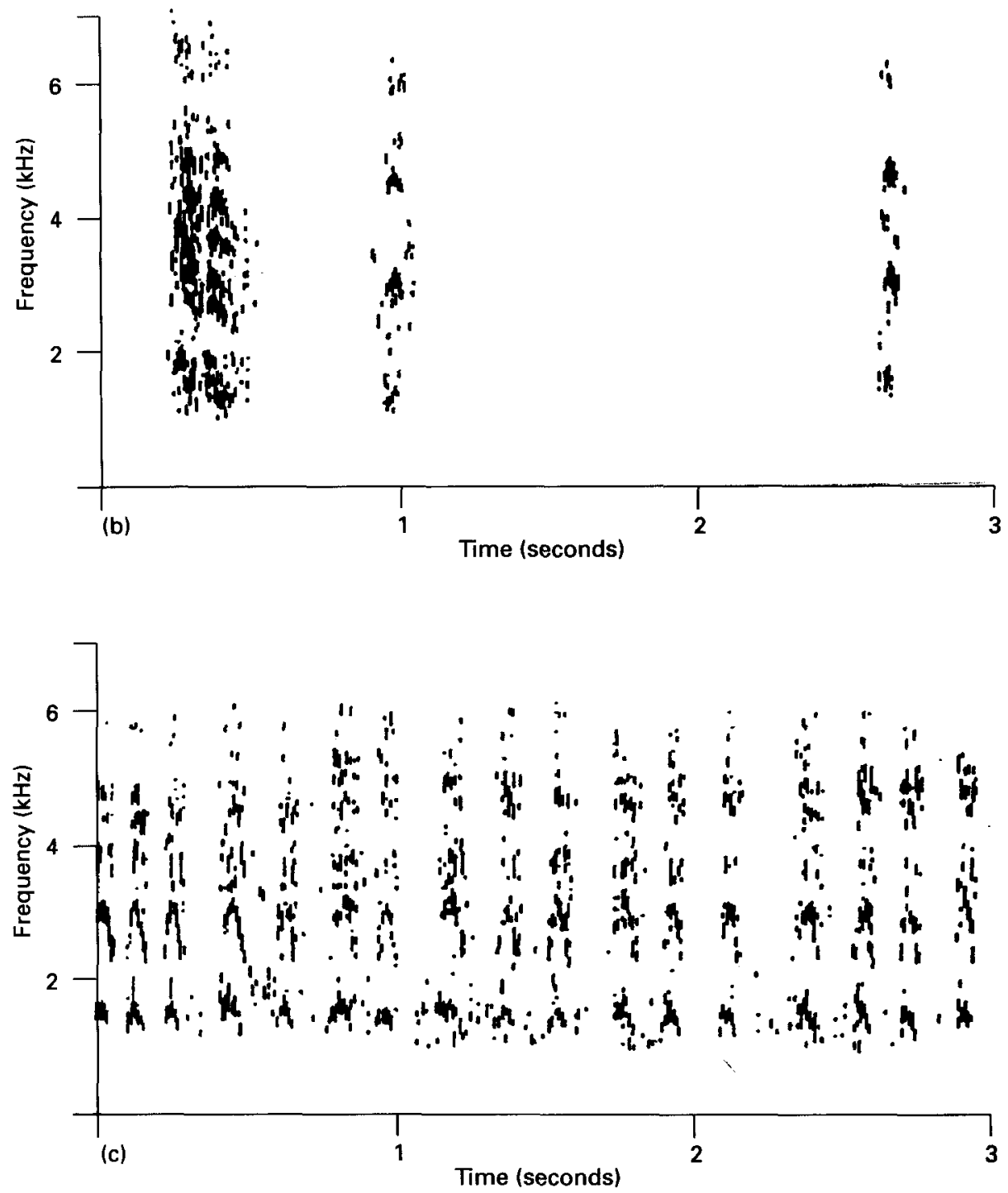

Figure 2 (cont.)

Juvenile food-begging call A noisy high-pitched single note was delivered when the juvenile wanted feeding. The call was constantly repeated and accompanied by vigorous wing-beating and an occasional peck at the adult bird's beak. This occurred whilst the birds visited Mollia gracilis and some calls continued for periods of up to six minutes before the bird was rewarded with food. The juvenile food-begging call is similar to that of an immature El Oro Parakeet Pyrrhura orcesi in being shorter and slightly higher-pitched than the adult's typical foraging call (Ridgely and Robbins 1988). Juvenile El Oro Parakeets behaved in a similar manner to the young White-breasted Parakeet when wanting food from the adults (see Ridgely and Robbins 1988). 


\section{Discussion}

The White-breasted Parakeet is known from three general locations: Cordillera de Cutucú, the Cordillera del Condor and in and around the Podocarpus National Park. This survey has extended its range from the west slope of the Cordillera de Cutucú south to Quebrada Honda, an approximate distance of $185 \mathrm{~km}$. By latitude $P$. albipectus ranges from Quebrada Honda east to the Cordillera de Cutucú, a distance of $85 \mathrm{~km}$. The species was found inhabiting forests between 940 and $1,800 \mathrm{~m}$, and our sighting of birds at the former altitude extends the elevational range of this parakeet. It is possible that it may be found at $900 \mathrm{~m}$ north of the park boundary, from where birds were observed flying.

The parakeet appears to be a common permanent resident around the Río Bombuscara area of Podocarpus National Park. It has been seen there in the months of February, March, April, May, October, November and December (Platt 1989, Bloch et al. 1991, C. Rahbek et al. verbally 1992, pers. obs.). The new sightings in August and September confirm the species is resident in the area, as suggested by Bloch et al. (1991). It has not been seen in the remaining months owing to a lack of surveys at these times. This area may be threatened by illegal colonists who have cleared up to eleven plots of land for occupation and farming activities. Comparing the situation in 1990 to 1992, these activities had not developed further probably because the Ministry of Agriculture had prevented more colonists moving into the area. However, those already there are likely to increase the population.

Our observations of a juvenile indicates breeding in the Bombuscara region, for although no nest was found, it is unlikely a fledged parrot still dependent on its parents would fly far from its nest (Forshaw 1989). Breeding probably takes place in June or July, as the combined incubation and nestling period for small parrots is between 38 and 51 days (Forshaw 1989). However, for Maroontailed Parakeets the incubation period has been estimated to be around 25 days, with the first young leaving the nest seven weeks later (Rhodes 1970). If $P$. albipectus is similar, then breeding in the Bombuscara region may be in May. If the breeding season is from May to July it could explain why the parakeets were apparently absent in June and July (Ridgely 1981), as parakeet activity would be centred around nest-sites and therefore difficult to detect. The timing of breeding each year might vary depending on other factors such as the fruiting period of plants. It is also possible that during our fieldwork albipectus bred. The only other evidence of breeding in this species was the collection of a male in April with worn plumage and enlarged but shrinking testes in the Cordillera de Cutucú region, suggesting that it had just finished breeding in March (Collar et al. 1992). It is doubtful that hybridization with Maroon-tailed Parakeets occurs in this region as it might elsewhere (Robbins et al. 1987), since the latter have not been recorded in the Podocarpus National Park area (Bloch et al. 1991, Toyne and Jeffcote 1992).

At the Romerillos locality the parakeet has been observed in the months of January, April and May, at Quebrada Avionetta in November and May (C. Rahbek et al. verbally 1992, pers. obs.) and at Quebrada Danta in May. Owing to the lack of survey work in this area the parakeet is regarded as uncommon, but it is probably resident all year as it is at Bombuscara. 
The parakeet was observed inhabiting partially degraded habitat at Serranía, El Limón, Bombuscara, Curintza, Romerillos, Quebrada Danta, Quebrada Avionetta (areas A, B and C in Figure 1); and a severely deforested hillside at Quebrada Honda (area E). This suggests that the species can survive in somewhat degraded habitat. It was only located in one region of primary, undisturbed forest, between Dos Camas and San Luis (area D), which is inside the gold-mining concession area named Cumbinama. This overall area is threatened by gold-mining activities, as much of parts of the loop are in the Romerillos concession. At present the San Luis area is worked by small-scale artisanal mines (whose use of mercury has contaminated local rivers: Vallée 1992, Vallée et al. in press), although large multinational companies have explored the area and, having previously been refused permission to continue to prospect by DINAMI (the Eduadorian national directorate of mining), are currently awaiting ratification of this decision from an autonomous institute within the Ministry of Agriculture called INEFAN, which will ultimately decide whether future mining activity within the park is in the national interest (C. Grylls verbally 1992). If the concessions (Cumbinama is $c .11 \%$ of the park's area) are granted, large areas of suitable habitat for $P$. albipectus will be destroyed. This overall area is the only pristine forest in southern Ecuador to have officially protected status and provides the main watershed area for major parts of Loja province. It also holds six other threatened bird species (see Collar et al. 1992: 122). It therefore needs to be fully protected from gold-mining and any road development, particularly the intended Zamora-Loyola and Yangana-Numbala roads (Figure 1); if constructed, the former would pass through the San Luis area (F. López verbally 1992), splitting the park in two.

To assess the conservation importance of these known $P$. albipectus locations, surveys are needed in pristine subtropical forests to compare the species's status there with its occurrence in degraded habitat. Previous surveys have all been restricted to accessible areas. At present, Podocarpus National Park is the only protected area the parakeet is known to inhabit, since both the Cordillera de Cutucú and the Cordillera del Condor lack official protection. Despite their inaccessibility they will inevitably become damaged and they are already threatened by deforestation, gold exploration and the development of major roads (Collar et al. 1992, L. Suárez verbally 1992). Given the limited knowledge of the parakeet's distribution and breeding habits, Podocarpus National Park needs to be recognized as a significant area for safeguarding this uncommon, range-restricted parakeet and one which could continue to be if its protected status is properly respected.

\section{Acknowledgements}

This work is an output of the "Parrots in Peril" expeditions to southern Ecuador since 1990. Fabricio Costa Jr., Eduardo Cueva, Angel Hualpa, Sachin Kapila, Rodrigo Tapia, Colin Taylor and Domitille Vallée provided help in fieldwork and companionship throughout our stays in Ecuador. We are grateful to Hanne Bloch, Frederik Brammer, Michael Køie Poulsen, Carsten Rahbek and Jan Fischer Rasmussen of the Zoologisk Museum, Copenhagen, for use of unpublished sightings described in text as " $\mathrm{C}$. Rahbek et al. verbally 1992". We thank the Ministerio de Agricultura y Ganadería in Quito, Loja 
and Zamora for permission to work in Podocarpus National Park; Nancy Hilgert de Benavides and Juan Carlos Mathéus of Corporación Ornitológica del Ecuador (CECIA) for logistical support in Ecuador; Arcoiris for their help whilst the expeditions were in Podocarpus National Park; Dr David Neill and Ing. Miguel Moreno of the Museo Ecuatoriano de Ciencias Naturales, Quito, for help with the collection of botanical specimens; Professors Pennington and Wurdack, Drs Berg and Radcliffe-Smith and the staff of the Royal Botanic Gardens, Kew, for their aid in plant identification; Richard Ranft of BLOWS for sonagram production; and Mark Robbins, Niels Krabbe and Carsten Rahbek for kindly commenting on previous drafts. Lastly, we acknowledge the following sponsors who made the expeditions possible: Imperial College Exploration Board, Imperial College Biology Department, Royal Geographical Society, British Ornithologists' Union, Frederick Gregory Fund, Leicester Polytechnic Students' Union, Gilchrist Educational Trust, Mount Everest Foundation, The Parrot Society of the U.K., Barclays Bank, Rob Thompson Memorial Fund, Cage and Aviary Birds, Journey Latin America, East Productions Ltd. and Wildwings.

\section{References}

Bloch, H., Poulsen, M. K., Rahbek, C. and Rasmussen, J. F. (1991) A survey of the montane forest avifauna of the Loja province, southern Ecuador. Cambridge, U.K.: International Council for Bird Preservation (Study Report 49).

Calderón, S. (undated) Situación del Parque Nacional Podocarpus. Loja, Ecuador: Ministerio de Agricultura y Ganadería (unpublished).

Chapman, F. M. (1914) Descriptions of new birds from Ecuador. Bull. Amer. Mus. Nat. Hist. 33: 317-322.

Chapman, F. M. (1926) Distribution of bird-life in Ecuador. Bull. Amer. Mus. Nat. Hist. 55 .

Collar, N. J., Gonzaga, L. P., Krabbe, N., Madroño Nieto, A., Naranjo, L. G., Parker, T. A. and Wege, D. C. (1992) Threatened birds of the Americas: the ICBP/ILCN Red Data Book. Third edition (part 2). Cambridge, U.K.: International Council for Bird Preservation.

Forshaw, J. M. (1989) Parrots of the world. Third (revised) edition. London: Blandford Press.

IGM (1981a) NVII-B2, Río Sabinalla, 3781-1. 1:50,00o. Quito, Ecuador: Instituto Geográfico Militar.

IGM (1981b) NVII-A2, Zamora, 3881-IV. 1:50,000. Quito, Ecuador: Instituto Geográfied Militar.

Krabbe, N. (in prep.) Avifaunal notes from Cordillera del Condor, south-eastern Ecuador.

Lawrence, G. H. M. (1951) Taxonomy of vascular plants. New York: Macmillan.

Mori, S. M. and Prance, G. T. (1987) A guide to collecting Lecythidaceae. Ann. Missouri Bot. Gard. 74: 321-330.

Platt, D. (1989) Preliminary study of the birds of Podocarpus National Park. Unpublished. Rachowiecki, R. and Wagenhauser, B. (undated $[=1992])$ Climbing and hiking in Ecuador. Second edition. Channel Islands, U.K.: Guernsey Press (Brandt Enterprises).

Rhodes, B. (1970) Breeding the Black-tailed Conure. Avicult. Mag. 76: 141-142.

Ridgely, R. S. (1981) The current distribution and status of mainland Neotropical parrots. Pp.233-384 in R. F. Pasquier, ed. Conservation of New World parrots. Washington, D.C.: Smithsonian Institution Press for the International Council for Bird Preservation (Techn. Publ. 1).

Ridgely, R. S. and Robbins, M. B. (1988) Pyrrhura orcesi, a new parakeet from 
southwestern Ecuador, with systematic notes on the $P$. melanura complex. Wilson Bull. 100: $173-182$.

Robbins, M. B., Ridgely, R. S., Schulenberg, T. S. and Gill, F. B. (1987) The avifauna of the Cordillera de Cutucú, Ecuador, with comparisons to other Andean localities. Proc. Acad. Nat. Sci. Philadelphia 139: 243-259.

Toyne, E. P, and Jeffcote, M. T. (1992) Parrots in Peril - Ecuador 1990. London: Department of Biology, Imperial College, London, U.K. (draft expedition report).

Vallée, D. (1992) Environmental impact of gold mining in the Podocarpus National Park in southern Ecuador. London: M.Sc. thesis, Centre for Environmental Technology, Imperial College of Science, Technology and Medicine.

Vallee, D., Kapila, S. and Toyne, E. P. (in press) Gold mining in Podocarpus National Park. In D. E. Christensen, J. P. Feil, J. E. Madsen and K. Roumeloux, eds. Podocarpus National Park. Aarhus: University of Aarhus and Rainforest Group Nepenthes.

Wurdack, J. J. (1980) 183. Melastomataceae. In G. Harling and B. Sparre, eds. Flora of Ecuador no. 13. Gothenburg: Department of Systematic Botany, University of Gothenburg; and Stockholm: Section of Botany, Riksmuseum.

E. P. TOYNE

Department of Biology, Imperial College, London SW7 2BB, U.K.

M. T. JEFFCOTE

Environment City Trust Ltd., Town Hall, Leicester LE1 6BF, U.K.

J. N. FLANAGAN

48 Stuart Street, Leicester $L E_{3}$ oDW, U.K. 